\title{
Screening of selected plants for their effectiveness in the treatment of kidney stone
}

\author{
Susmita Gudulkar, Karishma Rajbhar, Himanshu Dawda and Usha Mukundan \\ Plant Biotechnology Laboratory, Department of Botany, Ramniranjan Jhunjhunwala College, Ghatkopar (West), Mumbai 400086, India
}

\section{Article Info}

Article history

Received 12 Decmber 2019

Revised 30 January 2020

Accepted 5 February 2020

Published online 30 June 2020

Keywords

Kidney stones

Lithotriptic

Cystolith

Raphides

\begin{abstract}
Kidney ailments have increased several folds in the last two decades. Kidney stones are one of the most common urinary tract problems to be found. It has been associated with increased risk of renal failure if not treated in the early stages. Kidney stones are well known as renal calculus. They are mainly composed of minerals like calcium oxalate. An interaction with the local practitioners in Raigad district of Maharashtra, India revealed that several plant species are being used as lithotriptic agents. A simple technique has been designed to evaluate the lithotriptic activity of extracts of leaves of Bauhinia purpurea L., seeds of Celosia argentea L. and seeds of Macrotyloma uniflorum (Lam.) Verdc. Cystoliths and raphides which are aggregation of minerals are used as target minerals and their dissolution by the extracts of these plants are used as technique for evaluating the efficacy of these plants as lithotriptic agents.
\end{abstract}

\section{Introduction}

India has a glorious past of traditional medical system. Botanically derived medicine has played a major role throughout the history. Traditional knowledge is a valuable system continuously developed over generations by tribal and rural communities and transmitted from one generation to the other orally. The documentation of the indigenous knowledge on the utilization of local plant resources by traditional practitioners is one of the main objectives of ethnobotanical research. As these traditional knowledge is fast disappearing with time due to lack of scientific research, analysis and written documents. The authentication of herbal drugs is the need of the day (Alok et al., 2013; Talele et al., 2012).

The information of medicinal plants properties have been gathered from centuries based on diverse medicinal systems like Ayurveda, Unani and Siddha. It was found by the WHO report, that $60 \%$ of the world's population depends predominantly on the traditional medicine while $80 \%$ population in developing countries mostly use traditional medicinal practices and herbal medicines as a primary healthcare. Exploration of traditional medicine is an interesting and scientifically significant task for the ethnobotanists (Ram et al., 2015). The process of calculi or stone formation is known as lithiasis. Lithiasis is concretion of material mainly mineral salts in any tissue of the body. Antilithics are the agents known for prevention from the formation of stone or promote the dissolution of formed calculi. The main stream medical management of kidney stone problems is

Corresponding author: Dr. Usha Mukundan

Plant Biotechnology Laboratory, Department of Botany, Ramniranjan Jhunjhunwala College, Ghatkopar (West), Mumbai 400086, India

E-mail: umukundan@hotmail.com

Tel.: +91-9869003389

Copyright $@ 2020$ Ukaaz Publications. All rights reserved.

Email: ukaaz@yahoo.com; Website: www.ukaazpublications.com expensive and may result in reoccurrence of the problems and the drugs used in the treatment also have a many side effect. Plant based medicines are effective and devoid of any such side effects (Choubey et al., 2010; Arya et al., 2017).

Herbal medicines are more effective with fewer side effects and reduce recurrence rate of kidney stone formation. Thus, it has gained much recognition for antilithiatic drug from natural sources. It is of greater importance and it is also future promising. Herbal medicines have many phytoconstituents which are helpful and beneficial in kidney stone treatment. Plant extracts contain phytochemicals that hinder stone formation by inhibiting synthesis or by agglomeration of crystals. Although, use of herbal medicine is popular and promising, it is fundamental to carry out further research to understand the pathophysiology of disease, mechanism of action of herbal medicines in order to develop an efficient and safe litholytic agent (Ram et al., 2015).

An ethnomedicinal survey was undertaken to gather information from traditional healers of various parts of Maharashtra, India to cure kidney stone. Most kidney stones are calcium stones, combined with oxalate, phosphate and some time with uric acid (Choubey et al., 2010; Arya et al., 2017). Many plants were being used for effective treatment of kidney stones, out of which Bauhinia purpurea L., Celosia argentea L., Macrotyloma uniflorum (Lam.) Verdc. were selected in the present study.

Our study shows the efficacy of leaves of $B$. purpurea, $C$. argentea and M. uniflorum seeds in the treatment of kidney stones. To demonstrate the effectiveness of these plants on mineral stones, the Ficuselastica leaves (containing cystolith) and Colocasia esculenta containing raphides were used. Cystolith is a term used for inorganic concretions generally of calcium carbonate and calcium oxalate, which are formed in cellulose matrix in special 
cells called lithocysts, generally found in the leaves of many species of Ficus. Raphides are needle shaped crystals of calcium oxalate occurring in clusters occurring widely in arums.

\section{Materials and Methods}

\subsection{List of plant selected for testing lithotriptic activity}

Target material for screening lithotriptic activity was cystolith of Ficus elastica leaves and raphides of Colocasia esculenta petiole.

\begin{tabular}{|l|l|l|}
\hline Plant name & Family name & Parts used \\
\hline Bauhinia purpurea & Caesalpiniaceae & Leaves \\
Celosia argentea & Amaranthaceae & Seeds \\
Macrotyloma uniflorum & Papilionaceae (Fabaceae) & Seeds \\
\hline
\end{tabular}

\subsection{Phytochemical analysis}

Leaves of $B$. purpurea, seeds of $C$. argentea and $M$. uniflorum were air dried for achieving the persistent weight. Extract was prepared by using dried powder of the plant material (size less than 180 micron) in ratio of 1:100 of solvent. For detection of phytochemicals, extracts were prepared in chloroform, acetone, $90 \%$ methanol and water by sonicating $1 \mathrm{~g}$ in $100 \mathrm{ml}$ of the respective solvent in an ultrasonic bath for $15 \mathrm{~min}$ at room temperature and corresponding filtrates were used for all phytochemical tests.

\subsection{Effect of plant extract on cystolith and raphides}

Extracts of B.purpurea leaves, C.argentea seeds and M. uniflorum seeds were prepared by using mortar and pestle.
The selected $1 \mathrm{~g}$ of plant material leaves were crushed in $10 \mathrm{ml}$ of distilled water. The extracts were then filtered with whatmann filter paper no. 1. The filtrate was then used for further studies. Free hand sections of leaves of $F$. elastica showing cystolithand petioles of $C$. sculenta showing raphides were treated with the plant extracts. These sections were incubated in the extract at $25 \pm 2{ }^{\circ} \mathrm{C}$ for $20-22$ h. Effects of the extracts on the cystoliths were observed by comparing photomicrographs taken before and after treatment. Cystolith and raphides were treated with normal water as a control. Micrographs of $F$. cystolith were taken at 10 x magnification using a Motic digital Microscope and their size was determined using the Motic plus version 2.0 software. The results are based on observation of thirty sections of $F$. elastica leaves (cystolith) and C. esculenta petiole (raphides) treated with the extracts. All experiments were repeated thrice to ensure reproducibility of these results.

\section{Results}

The phytochemical screening of extracts of B. purpurea leaves, showed presence of flavonoids, glycosides, polyphenols, saponin and steroid mainly. C. argentea seed extracts showed presence of chalcones, emodins, glycosides and polyphenols, whereas extracts of seeds of M. uniflorum showed presence of chalcones, emodins, glycosides, polyphenols and tannins. These results have been compiled in Tables 1-3.

Table 1: Phytochemical screening of extracts of leaves of Buahinia purpurea L.

\begin{tabular}{|c|c|c|c|c|c|}
\hline \multirow[t]{2}{*}{ Chemical constituents } & \multirow[t]{2}{*}{ Tests } & \multicolumn{4}{|c|}{ Extracts } \\
\hline & & $\mathrm{CH}$ & $\mathrm{AC}$ & $\mathrm{ME}$ & WA \\
\hline Alkaloids & $\begin{array}{l}\text { Dragendroff reagent } \\
\text { Wagner's reagent }\end{array}$ & - & - & - & - \\
\hline Amino acids & Amino acids test & + & + & - & - \\
\hline Anthocyanin & Anthocyanin test & - & - & - & - \\
\hline Antraquinone & Antraquinone test & - & - & - & - \\
\hline Carbohydrate & $\begin{array}{l}\text { Felhing's test } \\
\text { Benedict's test }\end{array}$ & $\begin{array}{l}+ \\
+\end{array}$ & - & - & - \\
\hline Cardiac glycosides & Baljet's test & - & - & - & - \\
\hline Chalcones & Chalcones test & + & - & - & - \\
\hline Coumarins & Coumarin test & - & - & + & - \\
\hline Emodins & Emodins test & + & - & - & - \\
\hline Flavonoids & $\begin{array}{l}\text { Pew's test } \\
\text { Sodium hydroxide test } \\
\text { Ammonium hydroxide test }\end{array}$ & $\begin{array}{l}- \\
-\end{array}$ & $\begin{array}{l}- \\
- \\
+\end{array}$ & $\begin{array}{l}- \\
+ \\
+\end{array}$ & $\begin{array}{l}- \\
-\end{array}$ \\
\hline Glycosides & $\begin{array}{l}\text { Kedde's test } \\
\text { Keller killani test }\end{array}$ & $\begin{array}{l}+ \\
-\end{array}$ & $\begin{array}{l}+ \\
-\end{array}$ & - & - \\
\hline Leucoanthocyanin & Leucoanthocyanin test & - & - & + & + \\
\hline Polyphenol & Folin's ciocalteau & - & - & + & + \\
\hline Proteins & Proteins test & - & - & - & - \\
\hline Saponin & Foam test & + & + & + & - \\
\hline Steroids & Salkowski's test & + & + & + & + \\
\hline Tannin & Tannin test & - & + & - & - \\
\hline Terpenoids & $\begin{array}{l}\text { Anisaldehyde reagent } \\
\text { Vanillin-sulphuric acid reagent }\end{array}$ & - & $\begin{array}{l}+ \\
-\end{array}$ & - & - \\
\hline
\end{tabular}

(CH: Chloroform; AC: Acetone; ME: $90 \%$ Methanol; WA: Water) 
Table 2: Phytochemical screening of extracts of seeds of Celosia argentea L.

\begin{tabular}{|c|c|c|c|c|c|}
\hline \multirow[t]{2}{*}{ Chemical constituents } & \multirow[t]{2}{*}{ Tests } & \multicolumn{4}{|c|}{ Extracts } \\
\hline & & $\mathrm{CH}$ & $\mathrm{AC}$ & $\mathrm{ME}$ & WA \\
\hline Alkaloids & $\begin{array}{l}\text { Dragendroff reagent } \\
\text { Wagner's reagent }\end{array}$ & - & $\begin{array}{l}- \\
-\end{array}$ & - & - \\
\hline Amino acids & Amino acids test & + & + & - & - \\
\hline Anthocyanin & Anthocyanin test & - & - & - & - \\
\hline Antraquinone & Antraquinone test & - & - & - & - \\
\hline Carbohydrate & $\begin{array}{l}\text { Felhing's test } \\
\text { Benedict's test }\end{array}$ & $\begin{array}{l}+ \\
+\end{array}$ & $\begin{array}{l}+ \\
+\end{array}$ & - & - \\
\hline Cardiac glycosides & Baljet's test & - & - & - & - \\
\hline Chalcones & Chalcones test & + & + & + & + \\
\hline Coumarins & Coumarin test & - & - & - & - \\
\hline Emodins & Emodins test & + & + & + & + \\
\hline Flavonoids & $\begin{array}{l}\text { Pew's test } \\
\text { Sodium hydroxide test } \\
\text { Ammonium hydroxide test }\end{array}$ & $\begin{array}{l}- \\
- \\
-\end{array}$ & $\begin{array}{l}- \\
- \\
-\end{array}$ & $\begin{array}{l}- \\
-\end{array}$ & - \\
\hline Glycosides & $\begin{array}{l}\text { Kedde's test } \\
\text { Keller killani test }\end{array}$ & + & $\begin{array}{l}+ \\
-\end{array}$ & $\begin{array}{l}+ \\
-\end{array}$ & + \\
\hline Leucoanthocyanin & Leucoanthocyanin test & - & - & - & - \\
\hline Polyphenol & Folin's ciocalteau & + & + & + & + \\
\hline Proteins & Proteins test & - & - & - & - \\
\hline Saponin & Foam test & - & - & - & - \\
\hline Steroids & Salkowski's test & - & - & - & - \\
\hline Tannin & Tannin test & - & - & - & - \\
\hline Terpenoids & $\begin{array}{l}\text { Anisaldehyde reagent } \\
\text { Vanillin-sulphuric acid reagent }\end{array}$ & $\begin{array}{l}- \\
-\end{array}$ & - & - & - \\
\hline
\end{tabular}

(CH: Chloroform; AC: Acetone; ME: $90 \%$ Methanol; WA: Water)

Table 3: Phytochemical screening of extract of seeds of Macrotyloma uniflorum (Lam.) Verdc.

\begin{tabular}{|c|c|c|c|c|c|}
\hline \multirow[t]{2}{*}{ Chemical constituents } & \multirow[t]{2}{*}{ Tests } & \multicolumn{4}{|c|}{ Extracts } \\
\hline & & $\mathrm{CH}$ & $\mathrm{AC}$ & ME & WA \\
\hline Alkaloids & $\begin{array}{l}\text { Dragendroff reagent } \\
\text { Wagner's reagent }\end{array}$ & - & - & - & $\begin{array}{l}- \\
-\end{array}$ \\
\hline Amino acids & Amino acids test & - & + & - & - \\
\hline Anthocyanin & Anthocyanin test & - & - & - & - \\
\hline Antraquinone & Antraquinone test & - & - & - & - \\
\hline \multirow[t]{2}{*}{ Carbohydrate } & Felhing's test & + & + & - & - \\
\hline & Benedict's test & + & + & - & - \\
\hline Cardiac glycosides & Baljet's test & - & - & - & - \\
\hline Chalcones & Chalcones test & + & + & + & + \\
\hline Coumarins & Coumarin test & - & - & - & - \\
\hline Emodins & Emodins test & + & + & + & + \\
\hline \multirow[t]{3}{*}{ Flavonoids } & Pew's test & - & - & - & + \\
\hline & Sodium hydroxide test & - & - & - & - \\
\hline & Ammonium hydroxide test & - & - & - & - \\
\hline \multirow[t]{2}{*}{ Glycosides } & Kedde's test & + & + & + & + \\
\hline & Keller killani test & - & - & - & - \\
\hline Leucoanthocyanin & Leucoanthocyanin test & - & - & - & - \\
\hline Polyphenol & Folin'sciocalteau & + & + & + & + \\
\hline Proteins & Proteins test & + & + & + & + \\
\hline Saponin & Foam test & - & - & - & - \\
\hline Steroids & Salkowski's test & - & - & - & - \\
\hline Tannin & Tannin test & + & + & + & + \\
\hline \multirow[t]{2}{*}{ Terpenoids } & Anisaldehyde reagent & - & - & - & - \\
\hline & Vanillin-sulphuric acid reagent & - & - & - & - \\
\hline
\end{tabular}

(CH: Chloroform; AC: Acetone; ME: 90\% Methanol; WA: Water) 
F. elastica leaf sections showing cystolith were used for the study. Extract of $B$. purpurea leaves, seeds of $C$. argentea and M. uniflorum were used to observe their lithotriptic activity on cystolith and raphides. It was seen that after $20 \pm 2 \mathrm{~h}$ of treatment, the cystolith had completely dissolved leaving behind the peg which is made of

Table 4: Effect of plant extract on cystolith and raphides

\begin{tabular}{|c|c|}
\hline Plant extract & Extract of plant part used \\
\hline $\begin{array}{l}\text { Control (water) } \\
\text { Bauhinia purpurea } \\
\text { Celosia argentea } \\
\text { Macrotylomauniflorum } \\
\text { Control (water) } \\
\text { Bauhinia purpurea } \\
\text { Celosia argentea } \\
\text { Macrotylomauniflorum }\end{array}$ & $\begin{array}{l} \\
\text { Leaves } \\
\text { Seeds } \\
\text { Seeds } \\
- \\
\text { Leaves } \\
\text { Seeds } \\
\text { Seeds }\end{array}$ \\
\hline
\end{tabular}

Photoplate 1: Control - Ficus elastica leaf section showing cystolith before (A) and after (B) treatment with water.

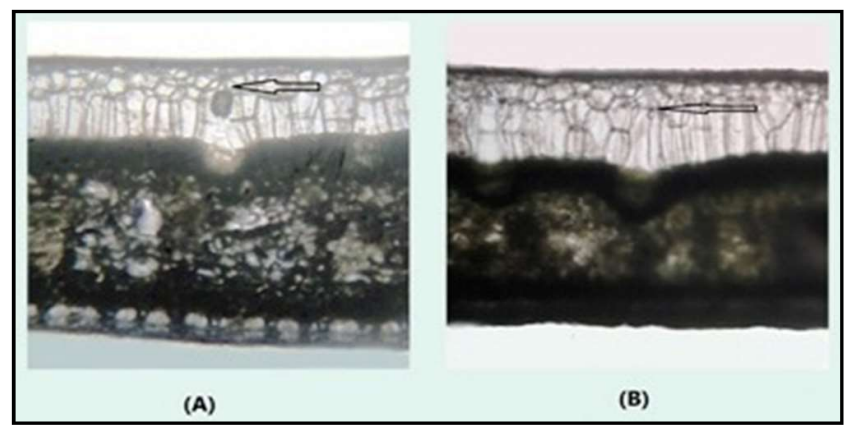

Photoplate 2: Ficus elastica leaf section showing cystolith before (A) and after (B) treatment with Bauhinia purpurea extract of leaves.

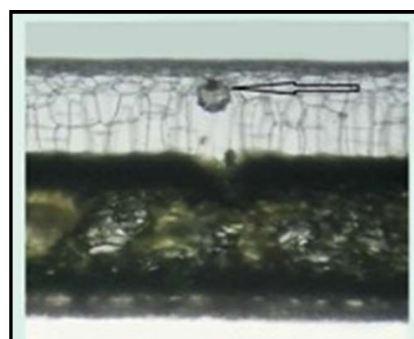

(A)

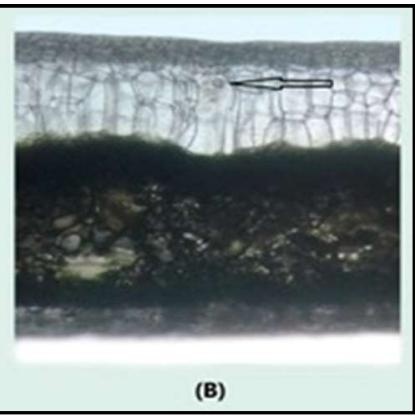

Photoplate 3: Ficus elastica leafs ection showing cystolith before (A) and after (B) treatment with Celosia argentea extract of seeds. cellulose, whereas the raphides of $C$. esculenta petiole had completely dissolved. Control sections were treated with distilled water and in these sections, cystolith and raphides remained intact even after twenty four hour of treatment. These results are summarised in Table 4.

\begin{tabular}{|l|l|}
\hline Effect on Ficus cystolith and Colocasia raphides & Photoplate \\
\hline No effect & No 1 \\
Dissolution of cystolith & No 2 \\
Dissolution of cystolith & No 3 \\
Dissolution of cystolith & No 4 \\
No effect & No 5 \\
Complete dissolution of raphides & No 6 \\
Complete dissolution of raphides & No 7 \\
Complete dissolution of raphides & No 8 \\
\hline
\end{tabular}



Photoplate 4: Ficus elastica leaf section showing cystolith before (A) and after (B) treatment with Macrotyloma uniflorum extract of seeds.



(A)

Photoplate 5: Control - Colocasia esculenta raphides before (A) and after treatment (B) with distil water.

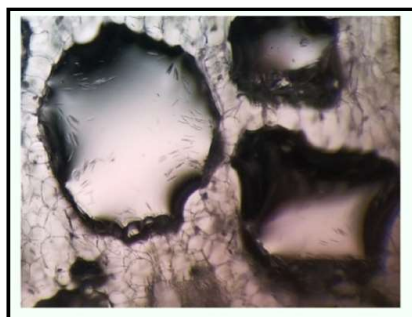

(A)
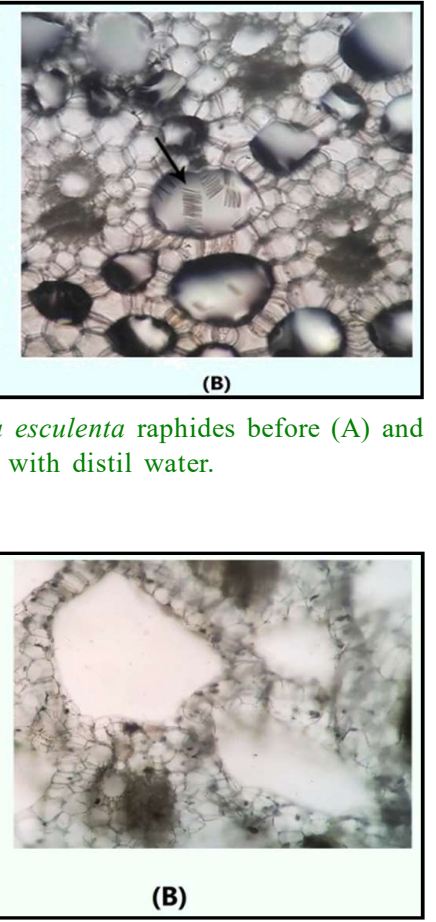

(B)
Photoplate 6: Colocasia esculenta section showing raphides before (A) and after (B) treatment with Bauhinia purpurea extract of leaves. 


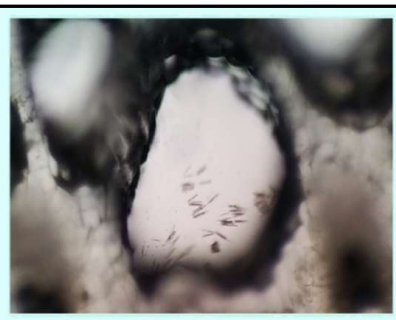

(A)

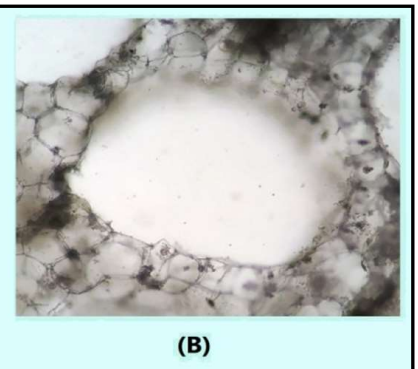

(B)
Photoplate 7: Colocasia esculenta section showing raphides before (A) and after (B) treatment with Celosia argentea extract of seeds.

\section{Discussion}

Herbal extracts are like diuretic in nature and have crystallization inhibiting activity, lithotriptic activity, analgesic and antiinflammatory activity which can be used to prevent stone formation. Celosia roots are used for urolithic activity (Ahmed et al., 2016), method used for the study is fruitful as it shows a visible results, hence it can be screened easily whether seeds also have same effect or not. A detailed further research is essential for the study of interactions and its adverse effects, it will also help in identifying the active principles compound from medicinal plants for assess their dosage and quality control.

Ethanobotanical studies have mentioned the use of many plants in treatment of kidney stone. Some of the plants like Bauhinia acuminate bark and leaf, Celosia argentea roots and many other have been listed (Arya et al., 2017). Herbal medicine is popular and promising but still it is essential to carry out further detailed research to understand the disease and the action mechanism of herbal medicines in order to develop a best efficient and safe lithotriptic agent. Clinical trials on animals are a must for the dosage and quality control study. Substitution of animals is what most people think of when you say alternatives to animal testing. Mostly, it is tried to replace the animals either by methods that does not involve animals at all (absolute replacement) or only the cells or tissues of animals (relative replacement) are used. Our method provides absolute replacement as it involves plant cells having mineralisation as a test subject.

\section{Conclusion}

Animals and plants follow the same process for the formation of calcium oxalate crystals. This method of treating plant cystolith and raphides with ethnomedicine can be used as a screening process for the drug claiming lithotropic activity in a simpler way. Hence, the mechanism of dissolution of crystals in plant cells by imaging technique can be used to validate the herbal medicine for the treatment of kidney stones.

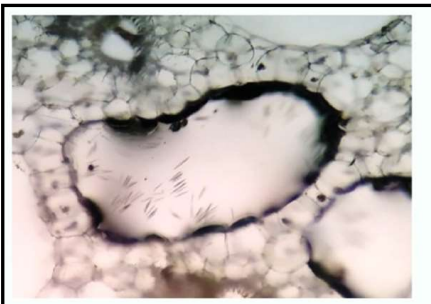

(A)



(B)
Photoplate 8: Colocasia esculenta section showing raphides before (A) and after (B) treatment with Macrotyloma uniflorum extract of seeds.

\section{Conflict of interest}

The authors declare that there are no conflicts of interest in the course of conducting the research. All the authors had final decision regarding the manuscript and decision to submit the findings for publication.

\section{References}

Ahmed, S.; Hasan, M. M. and Mahmood, Z. A. (2016). Antiurolithiatic plants in different countries and cultures. Journal of Pharmacognosy and Phytochemistry, 5(1):102.

Alok, S.; Jain, S. K.; Verma, A.; Kumar, M. and Sabharwal, M. (2013). Pathophysiology of kidney, gallbladder and urinary stones treatment with herbal and allopathic medicine: A review. Asian Pacific Journal of Tropical Disease, 3(6):496-504.

Arya, P.; Pandey, S. and Verma, V. (2017). Kidney stone formation and use of medicinal plants as antiurolithiatic agents. Universal Journal Pharmaceutical Sciences and Research, 2:43-48.

Choubey, A.; Parasar, A.; Choubay, A.; Iyer, D.; Pawar, R. S. and Patil, U. K. (2010). Potential of medicinal plants in kidney, gall and urinary stones. International Journal of Drug Development and Research, 2(2):431447.

Gudulkar, S.; Rajbhar, K.; Dawda, H. and Mukundan, U. (2016). Plant system as a tool for validating ethnobotanical claims for kidney stone treatment. World Journal of Pharmaceutical Research, 5(6):9.

Ram, J.; Moteriya, P. and Chanda, S. (2015). An overview of some promising medicinal plants with in vitro anti-urolithiatic activity. Journal of Pharmacy, 5(5):23-28.

Talele, B. D.; Mahajan R. T.; Chopda M. Z. and Nemade N. V. (2012). Nephroprotective plants: A review. International Journal of Pharmacy and Pharmaceutical Sciences, 4(1):8-16. 